\title{
THE DESIGN OF A SMALL-SCALE GRANULATE PRODUCING MACHINE
}

\author{
Botond KEDVES, ${ }^{1}$ Attila GERGELY² \\ Sapientia Hungarian University of Transylvania, Faculty of Technical and Human Sciences Târgu Mureș, , \\ Târgu Mureș, Romania \\ ${ }^{1}$ kedvesbotond10@gmail.com \\ 2agergely@ms.sapientia.ro
}

\begin{abstract}
The aim of this paper is to present a granulate manufacturing machine that will be used for recycling plastics in a laboratory at the Sapientia University. In order to produce granulates of recycled plastics the plastic part has to be ground and then extruded. The extruded polymer filament then can be converted to granulates. We present the working principle, design steps, structure and 3D model of a small scale granulate producing machine with a cost-effective approach
\end{abstract}

Keywords: thermoplastics, polymer, granulate, design, 3D modeling.

\section{Introduction}

Polymer materials have become indispensable in everyday life in the past couple of decades. These materials, in different shape, form and purpose are used in the following areas: house-hold use accounts for $22 \%$, heavy industry $5 \%$, electrical industry $7 \%$, construction $18 \%$, packaging industry $38 \%$, agriculture $3 \%$ and the automotive industry and other industries use 7\%. [1]

Raw polymer material can be manufactured by the polymerization of monomers, resulting in high quality materials, or can be produced from used and discarded polymer material by recycling.

Producing high quality polymer material by the polymerization of monomers is in most cases not a sustainable process, since most of the monomers are produced from crude oil. Furthermore, it should be mentioned that this process is not an environmentally friendly process. [2]

Recycling of used polymeric material is a sustainable process and helps to solve the problem of handling plastic waste too. The first step of recycling plastic material is the selection process from other waste material. Plastic material in raw material form in general is either granulate or powder, however granulate is more desirable. In order to produce granulate from the selected plastic waste it has to pass through a production line. The first step is to grind the plastic waste. Next, the granulating process follows, that can be done by having the produced filaments at room temperature. [3] or at elevated temperature. [4]

When the filament is at room temperature, the grinded plastic waste is fed into an extruder machine that melts the plastic and produces a filament. Next, the plastic filament has to be cooled down. To cool the filament there are several methods, for example passing it through a water bath that absorbs the heat or the use ventilators. After the filament is hardened by the cooling step it is introduced into the granulate-producing machine that cuts it into the desired length. [3]

When the produced filaments are at elevated temperature at the end of the extruder there is an eccentric rotating knife that cuts the molten filaments as they come out from the tool of the extruder and then fall into a water bath for cooling proposes. This technique is more productive and typically used in the industry however it requires a large capital investment. [4]

In contrast, when keeping in mind a budget friendly approach the granulate machine that cuts the filament when it is at room temperature is a more viable approach. Thus the aim of this work is to design such a machine 


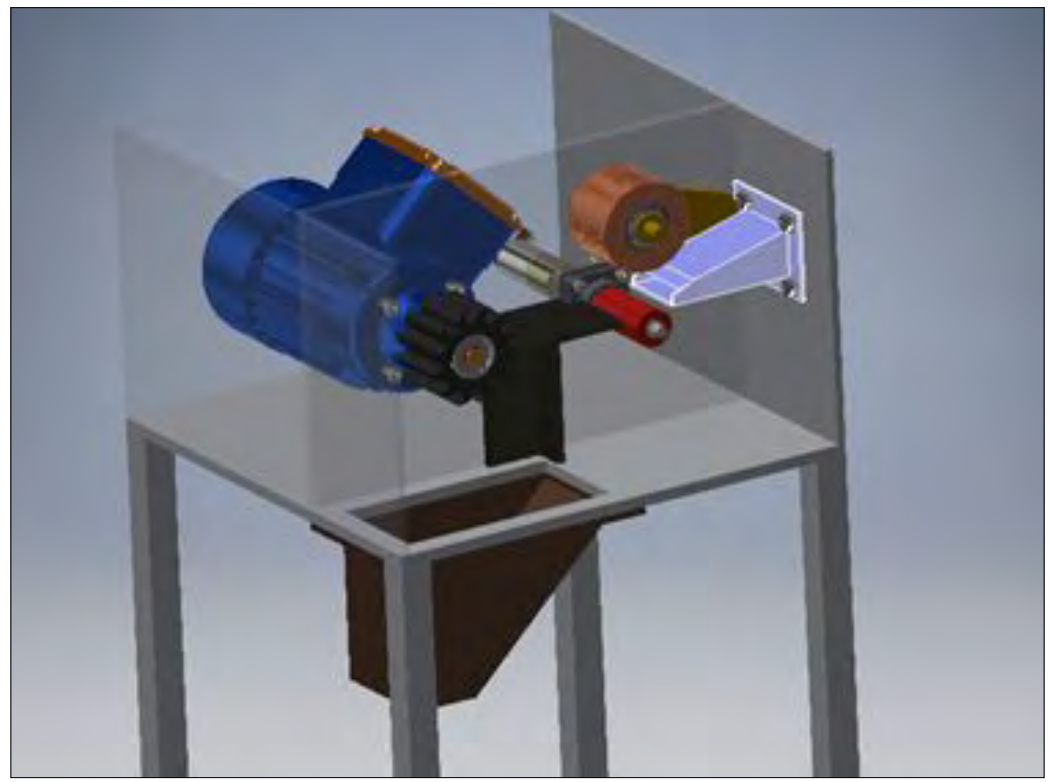

Figure 1. 3D model of the designed granulate-producing machine

\section{The designed granulate producing machine}

\subsection{Working principle and 3D modell}

Before the granulate-producing stage can be reached the grinded plastic is introduced into the extruder to produce a filament which is cooled to close to RT and fed into the granulate-producing machine through the feeding hopper. The feeding hopper is positioned in such a way that it guides the filament to the rollers that provide the continuous feeding. There are two rollers in the feeding mechanism. The upper roller can freely rotate with the aid of a bearing, and it is connected to a mechanism that allows the positioning of roller vertically. This provides the possibility of introducing filaments with different diameters in to the feeding mechanism. In order to produce a force onto the filament a spring is used, thus the filament is held between the two rollers. The lower roller is driven by a DC motor thus providing continuous feeding. By changing the rotational speed of the roller we can change the length of the produced filament. The plastic filament then proceeds to a component that guides the filament to the rotary knife and also serves as the stationary knife. The stationary knife is attached to the frame by bolts, in such a way that the vertical and horizontal position of the knife can be modified. A rotary knife then introduces shear stress along the cross-section of the filament that in turn cuts the filament and produces the granulate. The rotary knife is powered by an AC motor that has constant speed. The produced granulate then leaves the machine by another hopper, designed to guide the granulate to a collection basket.

\subsection{Components}

\subsubsection{Frame}

The frame is a complex part of the machine that provides the overall shape of the machine and it supports the different components. . The frame is built from steel plates and square shaped hollows. The frame is shown on Figure 2. The horizontal plate is manufactured from an $8 \mathrm{~mm}$ thick steel plate, OL50, that contains an opening for the granulate-guiding hopper. The dimension of the plate is $300 \times 300 \mathrm{~mm}^{2}$ and perpendicular to this can be found another plate that supports the rotary knife, the stationary knife and the rollers. The dimension of the plate is $300 \times 200 \mathrm{~mm}^{2}$. The frame furthermore contains two side plates. One of them contains an opening to feed the instrument and to connect the feeding hopper. The plates are welded together and supported by legs made out of 30x30x3 mm3 square hollows.

\subsubsection{Hoppers}

The hoppers are made of $2 \mathrm{~mm}$ thick sheet metal. After cutting each side of the hoppers, welding 


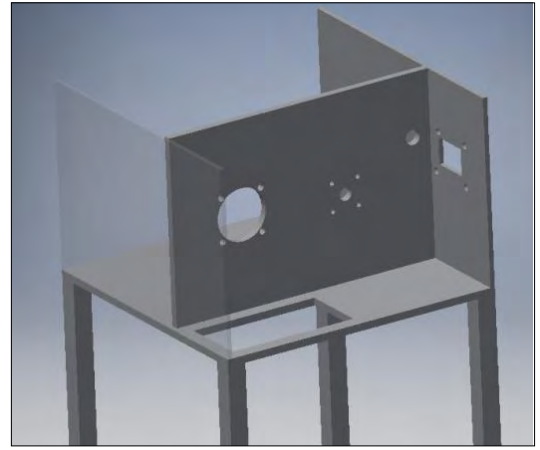

Figure 2. The frame

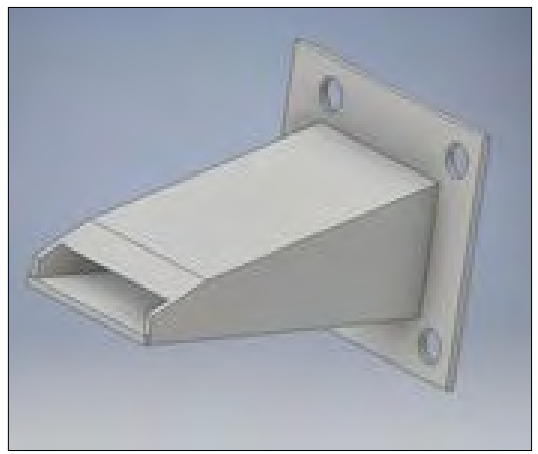

Figure 3. Feeding hopper

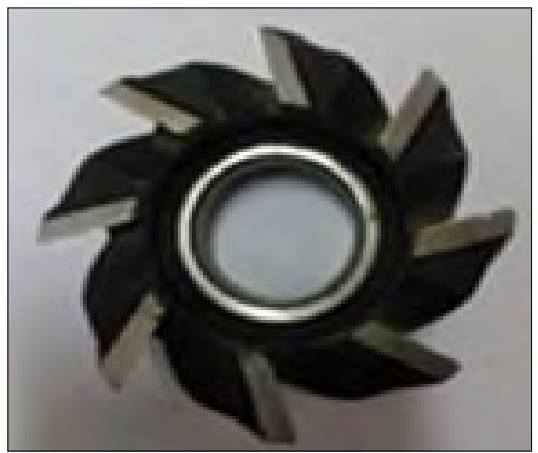

Figure 4. Knife: slab mill

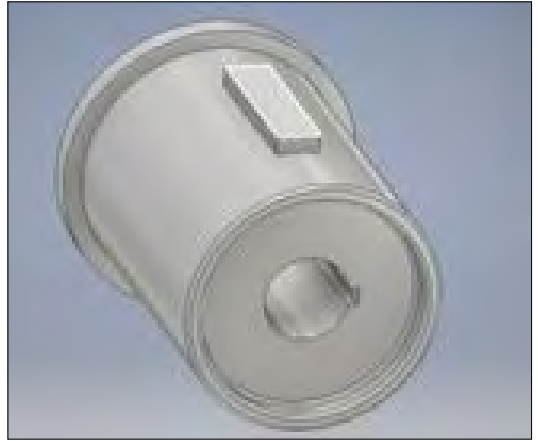

Figure 5. Connecting piece between the electric motor and the slab mill was used to join them together resulting in the shape presented in Figure 3. The feeding hopper only differs from the granulate-guiding hopper by its dimensions. Each hopper is joined to the frame by 4 bolts and washers. The opening of the feeding hopper is $8 \mathrm{~mm}$ in height that determines the maximum filament diameter that can be fed into the machine.

\subsubsection{Knife}

Keeping a budget friendly approach we have used a slab mill with 8 teeth instead of a specially designed rotary knife (Figure 4.). The outer diameter of the slab mill is $65 \mathrm{~mm}$, the width is 40 $\mathrm{mm}$, whereas the diameter of the hole is $28 \mathrm{~mm}$. The tooth height is $7 \mathrm{~mm}$ and the helix angel is $25^{\circ}$. Additionally, a connector piece is necessary to connect the rotary knife to the shaft of the AC motor. The connector is shown in Figure 5. In order to transmit the rotary motion and the torque key, joints are necessary both in the outer and inner diameter, which connect to the slab mill and shaft of the AC motor, respectively. The keys were dimensioned to the maximum power of the AC motor.

\subsubsection{Feeding}

The function of the rollers (Figure 6.) is to pull the filament into the machine and to transmit to the knives. Thus to prevent slippage between the surface of the rollers and the filament, tacky coating or rough roller surfaces should be used. The driven, lower, roller was obtained from a printer and has rubbery coating. The freely rotating upper roller is made of polyamide (PA6) with a textured surface. The upper roller applies a force to the filament that is achieved by a spring-loaded mechanism. In the feeding phase of granulate

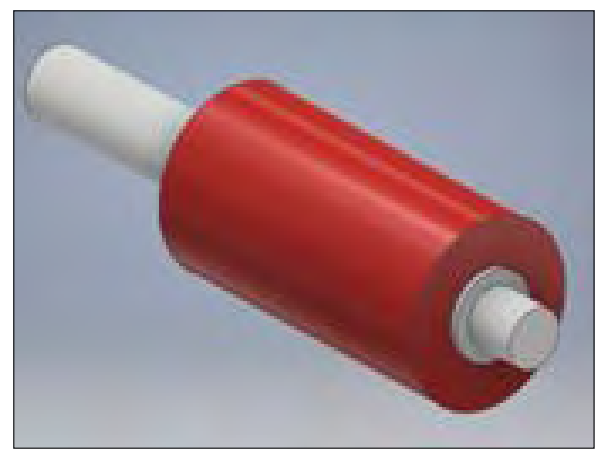

Figure 6. Roller with PA6 coating 
production this roller is moved vertically in order to feed the filament between the two rollers.

\subsubsection{Electric motors}

The slab mill is directly driven by a $0.09 \mathrm{~kW} 3$ phase AC motor. In order to be able to function the instrument from monophase $(220 \mathrm{~V})$, a $5 \mu \mathrm{F}$ capacitor is introduced in start wiring. The nominal rotational speed of the AC motor is $1350 \mathrm{rpm}$. In order to cut a filament that has a $3 \mathrm{~mm}$ diameter we need $9.75 \mathrm{~N}$, accounting for the shear stress of PET $1.38 \mathrm{MPa}$ at room temperature and area of the cross-section of the filament, $7.06 \mathrm{~mm} 2$. Multiplying the required force with the radius of the slab mill will result in the required torque, 0.32 $\mathrm{Nm}$, which translates to $0.045 \mathrm{~kW}$ power. [5] The $\mathrm{AC}$ motor is connected to the vertical plate by four bolts. The driven motor is a DC motor, POLOLU 25Dx54L, which can be controlled by the POLOLU $24 \mathrm{v} 23$ control unit. The control unit is equipped with a USB MINI connector and there is software to program it. The shaft diameter of the motor is $4 \mathrm{~mm}$, input voltage $6 \mathrm{~V}$, max rotational speed 78 rpm and 0,67 $\mathrm{Nm}$ torque. [6]

\section{Conclusions}

In this work we have presented the working principle, design and 3D model of a granulate-producing machine. The rotary knife type machine produces granulate with the aid of a slab mill. We have presented the frame, rotary knife and feeding mechanism of the instrument that are each specially designed. This machine will be used as a laboratory instrument to help students to familiarize themselves with the granulate production process.

\section{References}

[1] Müanyagtermelés és felhasználás napjainkban. https://sites.google.com/site/adhjfhaio/home/ muanyagtermeles-es-felhasznalas-napjainkban (letöltve: accessed on: $10^{\text {th }}$ February 2019).

[2] Rauwendaal C.: Polymer Extrusion. 4th ed.. Hanser, München, 2004.

[3] Giles H. F., Wagner J. R.: Extrusion: The Definitive Processing Guide and Handbook. Crescent Associates Inc., Rochester, New York, 2004.

[4] Air Cooling Hot Face Plastic Granulator PVC PP PE PS Pelletizing Line

https://cnbmjacky.en.made-in-china.com/product/HSumLsgOLDhZ/China-Air-Cooling-HotFace-Plastic-Granulator-PVC-PP-PE-PS-Pelletizing-Line.html (accessed on: $8^{\text {th }}$ January 2019.).

[5] Sulinet. Áthajtómüvek kialakitása, felépitése, szerkezeti részei, áthajtómüvek teljesítmény, nyomaték, fordulatszám viszonyai

https://tudasbazis.sulinet.hu/hu/szakkepzes/gepeszet/gepelemek/athajtomuvek-kialakitasa-felepitese-szerkezeti-reszei-athajtomuvek-teljesitmeny-nyomatek-fordulatszam-viszonyai/athajtomuvek-kulonbozo-viszonyai (accessed on: $9^{\text {th }}$ January 2019).

[6] Pololu Robotics and Electronics. 75:1 Metal Gearmotor 25Dx54L mm LP $6 \mathrm{~V}$ with 48 CPR Encoder https://www.pololu.com/product/2286/specs (accessed on: $20^{\text {th }}$ January 2019). 